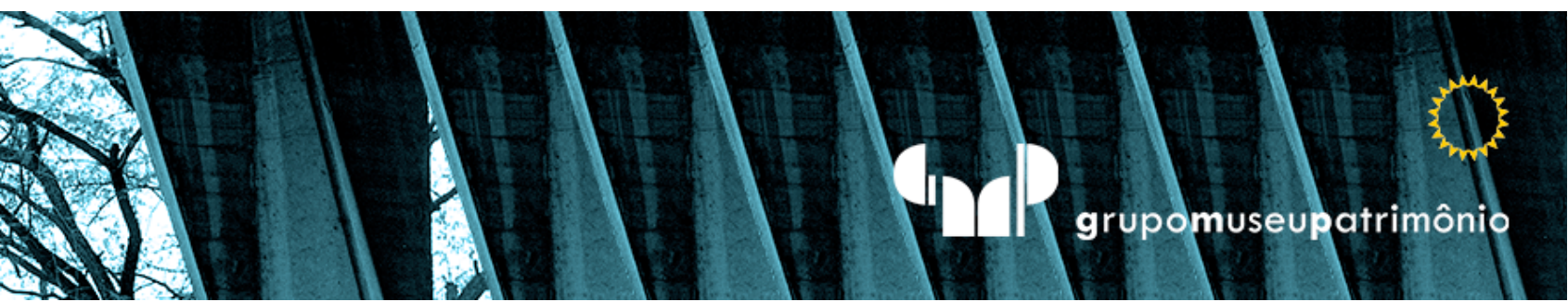

\title{
Fun Selfies: uma série de imagens sobre as imagens dos artistas.
}

\section{Fun Selfies: uma serie de imágenes sobre las imagénes de los artistas.}

\section{Funs Selfies: a series of images about the artist' images.}

\section{Marcos Rizolli}

Programa de Pós-Graduação em Educação, Arte e História da Cultura da Universidade Presbiteriana Mackenzie, São Paulo, Brasil. marcos.rizolli@mackenzie 


\title{
Resumo
}

A série de fotografias digitais Fun Selfies apresenta-se como atos artísticos interessados em pensar o universo das imagens artísticas por intermédio da apropriação de imagens dos próprios artistas, desconsiderando, inicialmente, as obras que produziram e que os destacaram na História da Arte. Para, posteriormente, resgatar as suas artisticidades em diálogos abertos com suas produções - visualidades, processos, métodos criativos.

Palavras-Chave: Arte Contemporânea. Poéticas Visuais. Crítica de Arte. Apropriação. Imagem.

\section{Resumen}

La serie de fotografía digital Fun Selfies se presenta como actos artísticos interesados en pensar el universo de las imágenes artísticas a través de la apropiación de imágenes de los propios artistas, desconociendo inicialmente las obras que produjeron y que las destacaron en la Historia del Arte. Para luego, rescatar sus artisticas en diálogos abiertos con sus producciones - visualidades, procesos, métodos creativos.

Palavras-Clave: Arte Contemporáneo. Poética visual. Crítica de arte. Apropiación. Imagen.

\begin{abstract}
The Fun Selfies digital photography series presents itself as artistic acts interested in thinking about the universe of artistic images through the appropriation of images by the artists themselves, initially disregarding the works they produced and that highlighted them in the History of Art. To, later, rescue their artisticities in open dialogues with their productions - visualities, processes, creative methods.
\end{abstract}

Keywords: Contemporary Art. Visual Poetics. Art Criticism. Appropriation. Image. 


\section{O OUTRO, EM ATOS.}

\footnotetext{
un Selfies, uma série de nove autorretratos, inspirada em retratos de artistas modernos e contemporâneos, paradigmáticos em suas artisticidades e em seus modos de viver e pensar a linguagem da arte, abre-se a um processo de apropriação de expressões faciais e gestos corporais diretamente emprestadas das figuraspersonalidades que the deram sopro.

Os autorretratos são imagens de contrastes', atos de citação e interpretação das imagens mediatizadas por esses artistas - reconhecidamente detentores de identidades carismáticas.

A ideia é bem essa: selecionar o artista e um de seus retratos; observar a alma da imagem; perceber peculiaridades; se apropriar das essências formais; refazer o outro, em ato fotográfico; tornar-se ele ou ela - sem deixar-me.
} 
Parafraseando van Gogh, diga-lhe que meu maior desejo é aprender a cometer também estas inexatidões, chegar a tais desvios, alterações, modificações da realidade, mentiras, se quiser. (Carta, 1882)

Ou, me aproximando do pensamento de Lionello Venturi:

Quando se fala da personalidade do artista, deseja-se falar do homem no momento no qual cria. Nesse momento ele é o representante do eterno da arte. Geralmente considera-se o contrário, que na obra de arte, o caráter individual é efêmero e contingente e construímos leis de arte, cuja observância constituiria o valor eterno da obra de arte. Mas, o estudo da história da arte, ou da história da crítica de arte, convenceu-me que são justamente as leis da arte que têm um caráter efêmero e contingente, valendo para um período ou escola, jamais para todos os tempos e lugares. Logo, a personalidade artística deve ser considerada como a própria lei. (VENTURI, 1969, p.145)

Nove vezes, um diálogo de fusões figurais, em busca de leis compartilhadas que, para o bem e para o mal, possam gerar uma lei particular - um ato potência ${ }^{2}$ que determine a minha arte. Ainda que seja uma arte, em tempo pandêmico, determinada pela despersonalização. Como requer Clarice Lispector em A paixão segundo G. H. - em ato de linguagem que provocou minhas reflexões:

A despersonalização como a destituição do individual inútil - a perda de tudo o que se possa perder e, ainda assim, ser. Pouco a pouco tirar de si [...] as características. Tudo o que me caracteriza é apenas o modo como sou mais facilmente visível aos outros e como termino sendo superficialmente reconhecível por mim. (LISPECTOR, 1979, p.170) 


\section{Ato 1 - A camisa listrada e o olhar transversal.}

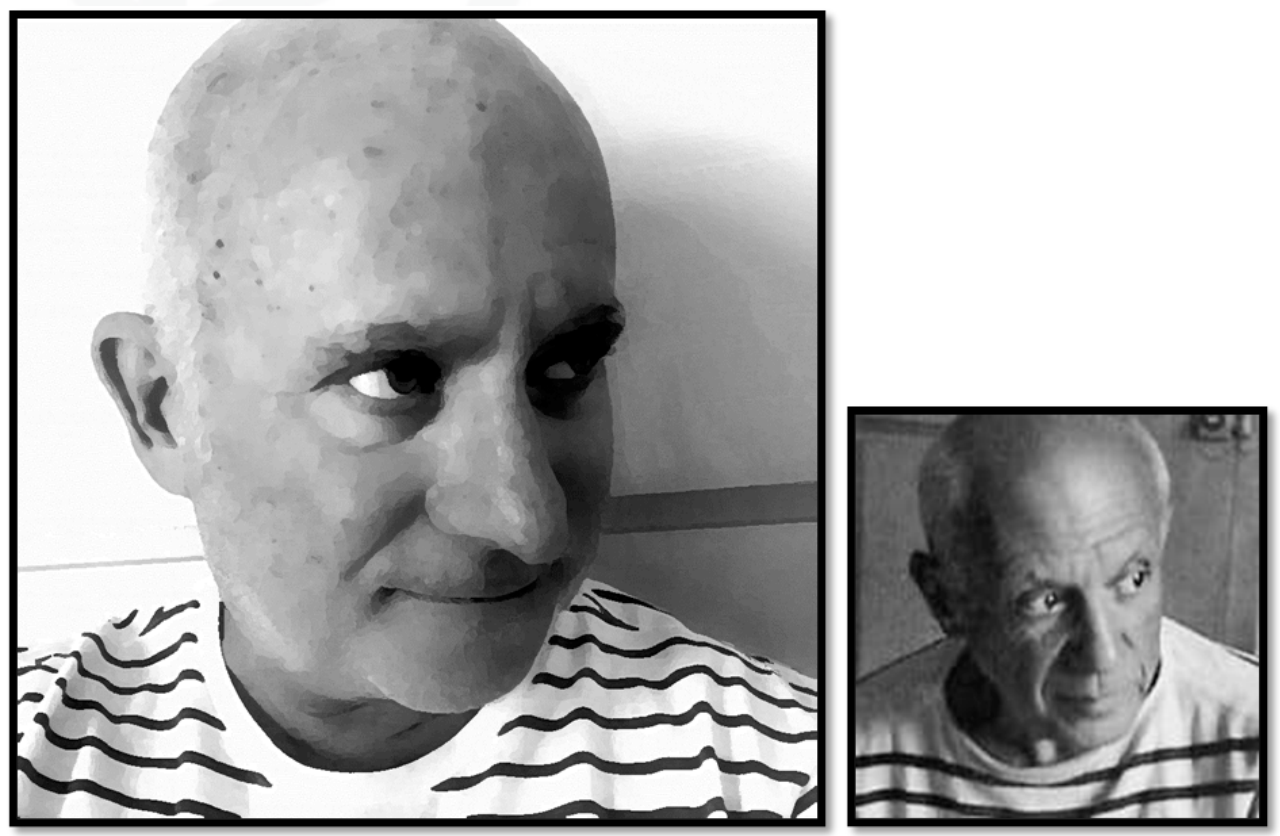

Figura 1: Pablo Picasso e Eu, imagem digital, 2020-21.

Figura 2: Retrato do artista, Robert Doisneau, reprodução fotográfica, 1952. Fonte: https://www.artsy.net/artwork/robert-doisneau-les-pains-de-picasso-1

O Cubismo, movimento artístico protagonizado pelo espanhol Pablo Picasso (1881 1973) exerceu uma transversalidade na linha do tempo da História da Arte. As imagens cubistas, linearmente definidas e geometricamente recortadas, parecem impregnar o retrato do artista. Da juventude à maturidade foi personalidade onipresente nos círculos artísticos de seu tempo. Sempre requisitado a se deixar fotografar aceitava os desafios de emprestar a sua própria imagem como forma de expressão de inúmeros fotógrafos.

Então, o olhar transversal, a roupa linear e a peculiar calva estruturaram o diálogo recursivo entre mim e ele. 


\section{Ato 2 - Sobre transparências e sobreposições.}

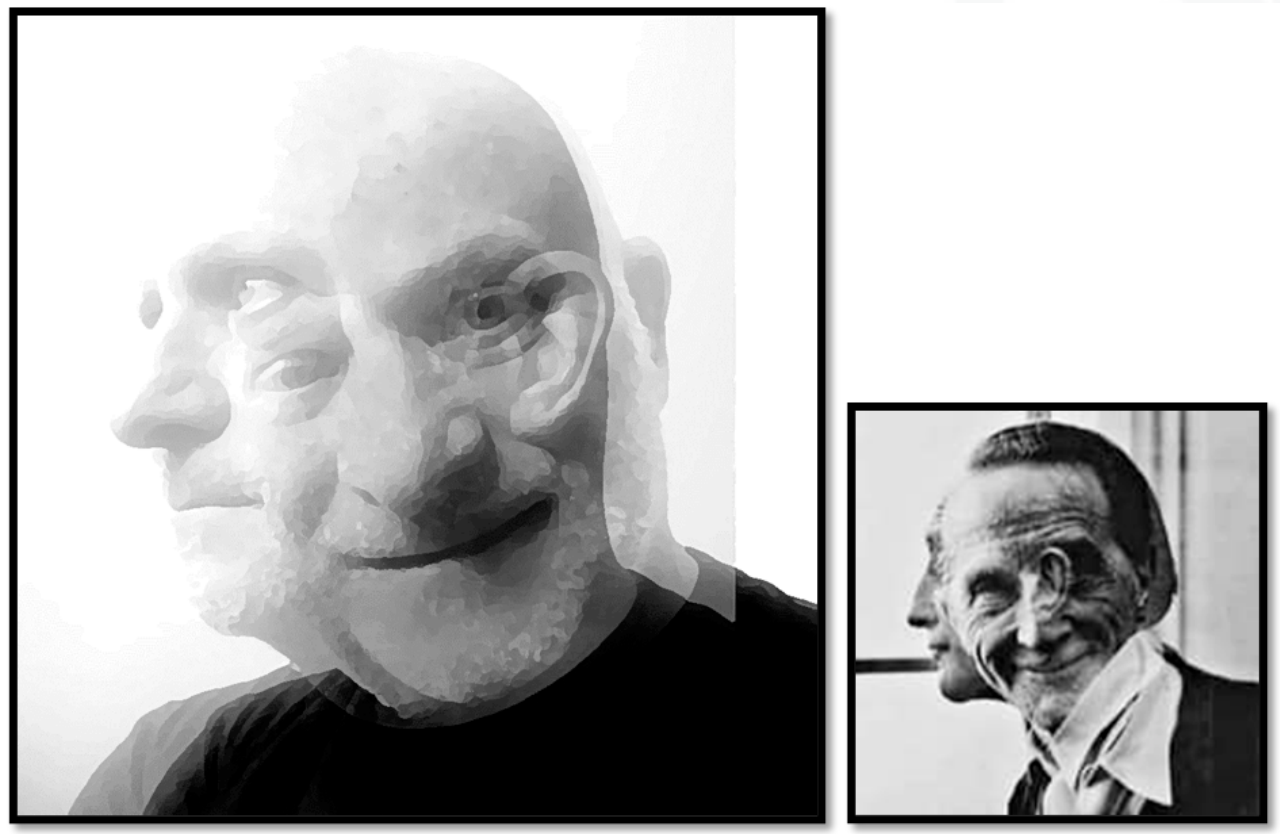

Figura 3: Marcel Duchamp e Eu, imagem digital, 2020-21. Figura 4: Foto da capa do livro de Artista concebido por Marcel Duchamp e Robert Lebel, traduzido por George H. Hamilton e publicado pela Grove Press, 1959. Fonte: https://www.artbook.com/9783906915517.html

O célebre O Grande Vidro (1912-23) obra magistral do dadaísta Marcel Duchamp (1887 - 1968) parece ser a plataforma expressiva que nos une - em nossas imagens.

Um dos mais notáveis artistas-celebridade, o francês Duchamp reivindicava uma arte intelectual em que o conceito de arte se sobrepunha à tradição da manualidade. Seus famosos ready-mades - objetos encontrados ou objetos prontos - advinham de experiências cotidianas.

O surpreendente e o corriqueiro sempre formaram o primo-motor criativo do artista.

Compreendendo a arte como um jogo, libertou o objeto artístico das esferas habilidosas das imagens. E me libertou, ao tempo que transparências e sobreposições me desmaterializam. 


\section{Ato 3 - Ora, bigodes!}
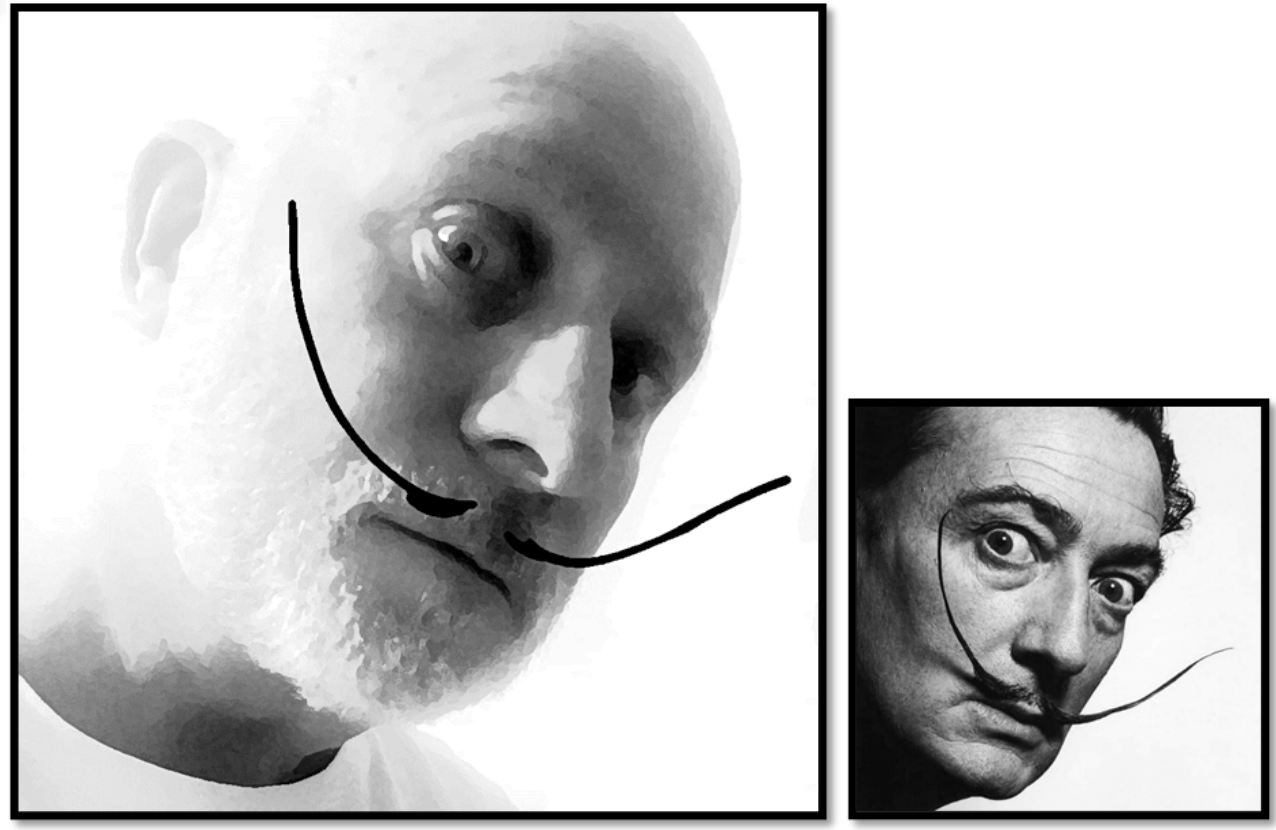

Figura 5: Salvador Dalí e Eu, imagem digital, 2020-21 Figura 6: Capa do livro La vida desaforada de Salvador Dalí, escrito por Ian Gibson e publicado pela Anagrama, 2006. Fonte: https://www.amazon.com.br/vida-desaforada-SalvadorDal\%C3\%AD/dp/8433907816

Talvez, a imagem que melhor represente a personalidade midiática do espanhol Salvador Dalí (1904 - 1989) seja aquela que apresenta seus afiados bigodes. Pode ser considerada um perfeito representante de suas figuras surrealistas longitudinalmente deformadas e anti gravitacionalmente compostas em suas pinturas.

Exaustivamente reproduzida, a fotografia percorre o imaginário coletivo acerca das categorizações dos artistas. Em seu caso: nada introspectivo e tudo excêntrico. $\mathrm{O}$ arco invertido formado pelo desenho dos bigodes emoldura a intensidade do olhar. Realizei-me Dalí em momento pandêmico em que me recuperava de uma paralisia facial provisória que comprometeu, então, minha acuidade visual. 


\section{Ato 4 - 0 imponderável chapéu e a onipresente maçã.}

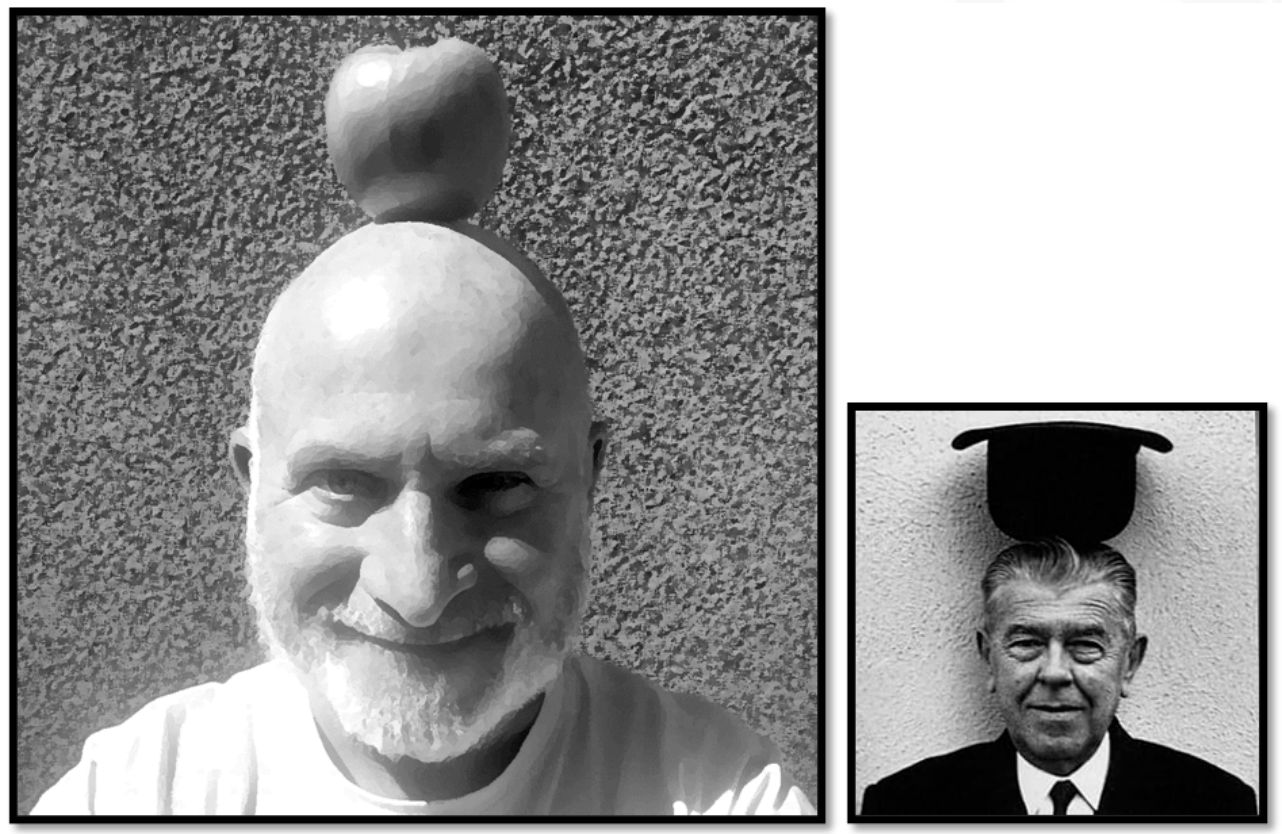

Figura 7: René Magritte e Eu, imagem digital, 2020-21.

Figura 8: Contracapa do livro René Magritte. Life Line, editado por Julie Waseige e publicado pela Skira, 2019. Fonte: https://www.amazon.com/Ren\%C3\%Ag-Magritte-Life-Line-

Rene/dp/8857238970

Aqui, entre mim e o pintor belga René Magritte (1898 - 1967), há um sistema de inversões. O universo surreal encontra sua síntese no chapéu e na maçã - elementos tão recorrentes em suas pinturas. O inusitado das figuras presta-se à formulação viso-conceitual do retrato do artista e do meu autorretrato - uma selfie. Os sorrisos contidos de um-e-outro determinam a atmosfera expressiva das frontalidades faciais, enquanto os objetos reafirmam o nonsense das imagens. O chapéu e a maçã acentuam a imponderabilidade dos objetos considerados reais em face à onipresença das formas da linguagem visual.

Então, lá e cá, um tênue equilíbrio e uma sutil permanência. 


\section{Ato 5 - Retratos angustiados.}
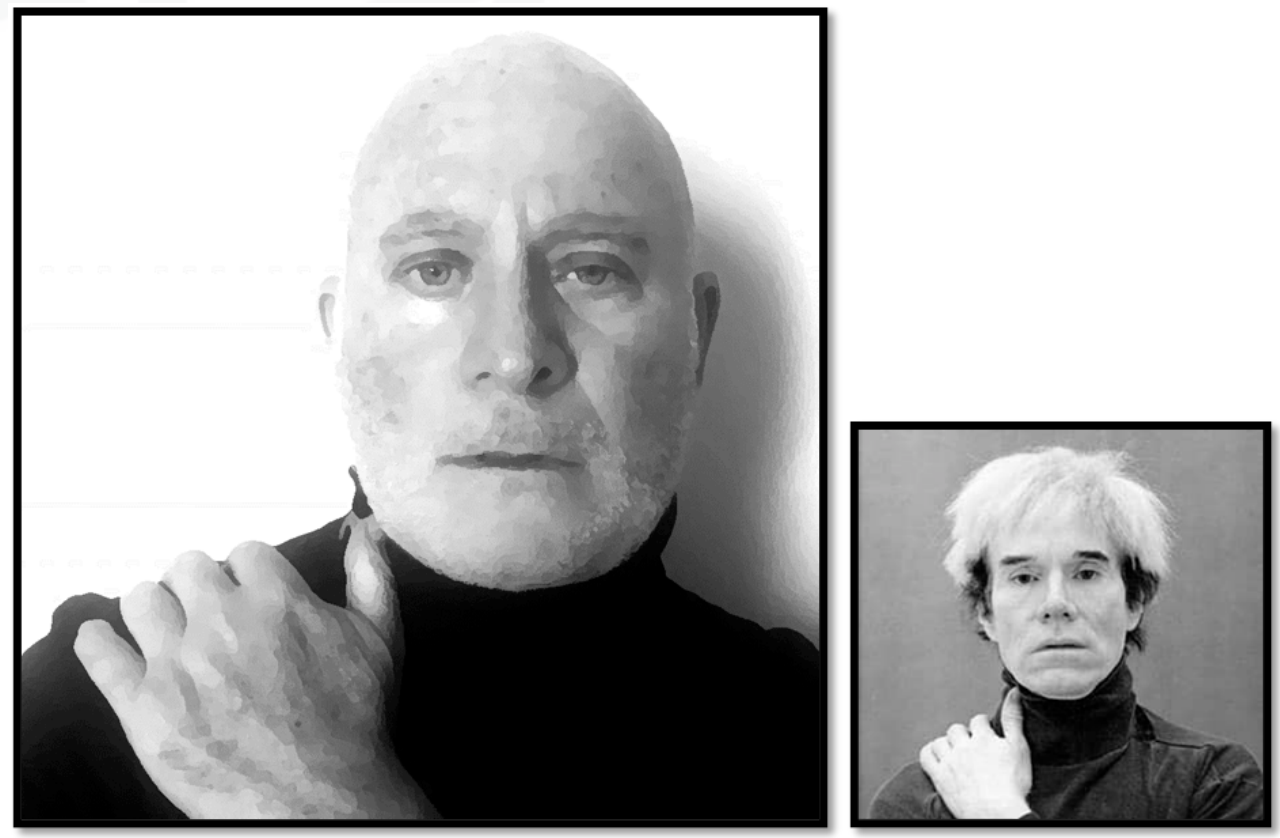

Figura 9: Andy Warhol e Eu, imagem digital, 2020-21. Figura 10: Foto do folder de divulgação de um ciclo de documentários sobre arte dos anos 60' e 70' promovido pela InLiquid, 2019. Fonte: https://inliquid.org/calendar/secret-cinemapresents-andy-warhol-and-friends-60-70s-art-documentaries/

A extravagante personalidade do norteamericano Andy Warhol (1928 - 1987) se confunde com a sua arte. Talvez não se compreenda a arte de Warhol, mas se reconheça o artista Warhol - imagem, por excelência!

Inúmeras vezes, modelo ou tema de sua produção gráfico-pictórica, exacerbou a clássica noção de autoimagem.

Angustiado com a própria existência e encantado com a imagem dos outros, perpassou os limites entre o artista, o retrato e o retratado. Sua postura Pop investiu no declínio da visualidade, rebaixou a técnica e banalizou os ícones da cultura. 


\section{Ato 6 - We want you!}
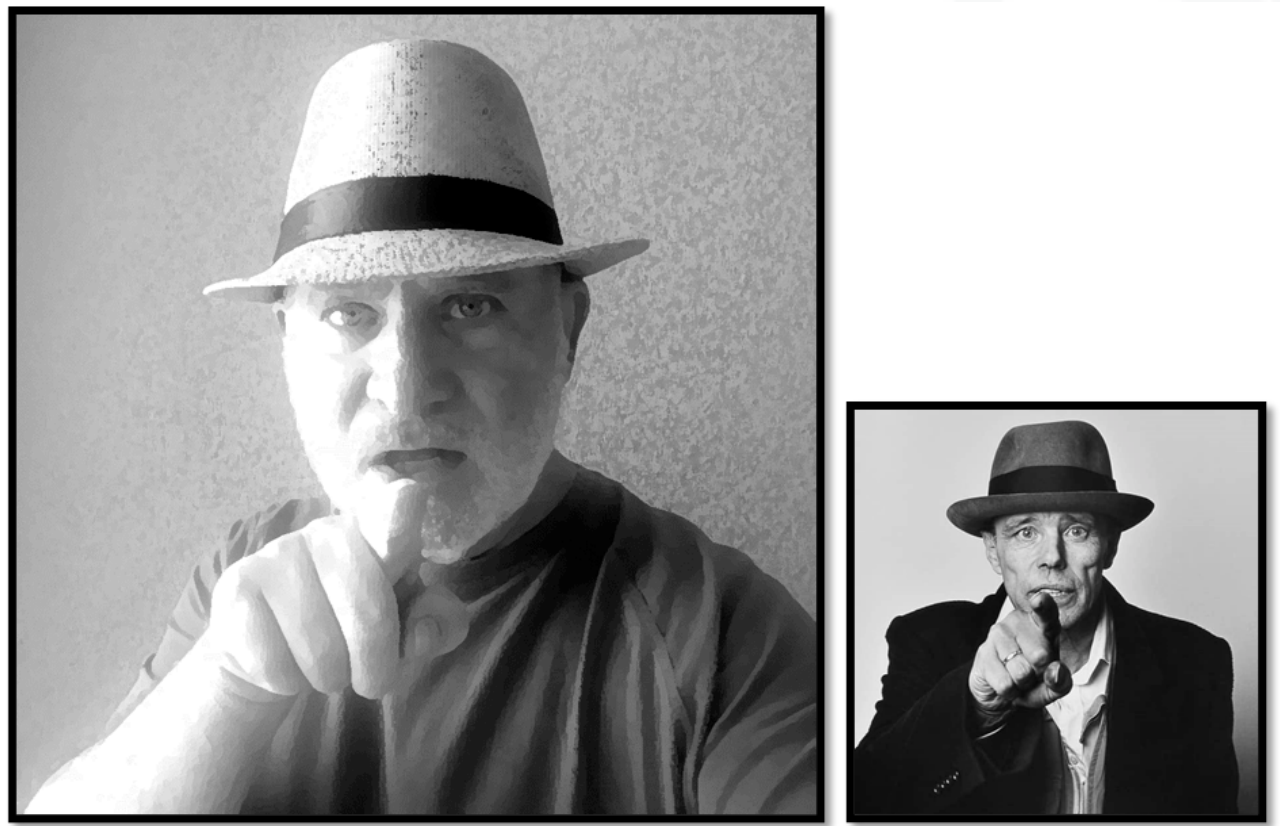

Figura 11: Joseph Beuys e Eu, imagem digital, 2020-21.

Figura 12: Foto da capa do livro Kunst Kapital Revolution, escrito por Philip Ursprung e publicado pela C.H.Beck, 2021. Fonte: https://www.chbeck.de/ursprung-josephbeuys/product/30934921

O alemão Joseph Beuys (1921 - 1986) se autodeclarou um artista social. Propositor de formas expressivas de difícil interpretação, protagonizou a diluição dos limites entre vida e arte, entre estética e política. Pretendeu uma arte ideológica e revolucionária. Assim como Magritte, Beuys fez uso identitário do chapéu. Em diferentes circunstâncias autenticou suas obras artísticas desenhando aquele objeto, em substituição da assinatura. Então, em minha selfie, o modelo de feltro, europeu, foi convertido numa versão de palha, tropical. Chapéus na cabeça, olhares incisivos e dedos em riste, convocamos nossos interlocutores para um diálogo contemporaneamente ecológico. 


\section{Ato 7 - Marcas na pele e olhar arteiro.}

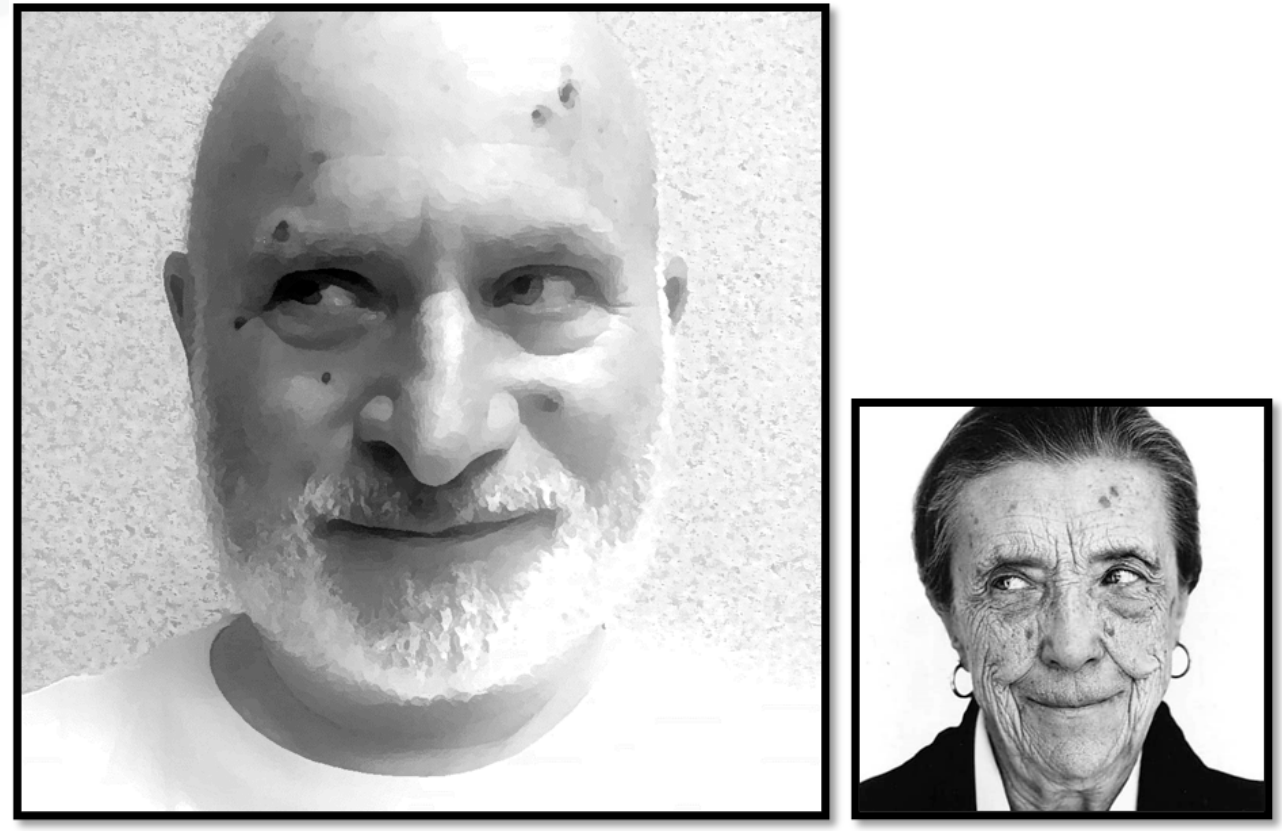

Figura 13: Louise Bourgeois e Eu, imagem digital, 2020-21.

Figura 14: Retrato da artista, Herb Ritts, impressão fotográfica comercializada pela Artsy, 1991. Fonte: https://www.artsy.net/artwork/herb-ritts-louise-bourgeois-new-york

Imagine forjar manchas, pintas e verrugas na pele do rosto utilizando uma rudimentar mistura de farinha de trigo e ketchup - com o intuito de conferir densidade e saturação. O efeito especial, pré-produção fotográfica, toscamente se assemelha com a materialidade disposta na contundente obra da artista francesa Louise Bourgeois (1911 - 2010).

Detentora de uma expressão multidimensional, experimentou infinitos materiais em diversificados procedimentos técnicos - para tratar de assuntos um tanto árduos e intimamente relacionados às circunstâncias diárias. Por um ímpeto de apropriação, o desejo de citar o retrato da artista me forçou a buscar recursos na cotidianidade do meu autorretrato pandêmico. 


\section{Ato 8 - Autorreferências.}
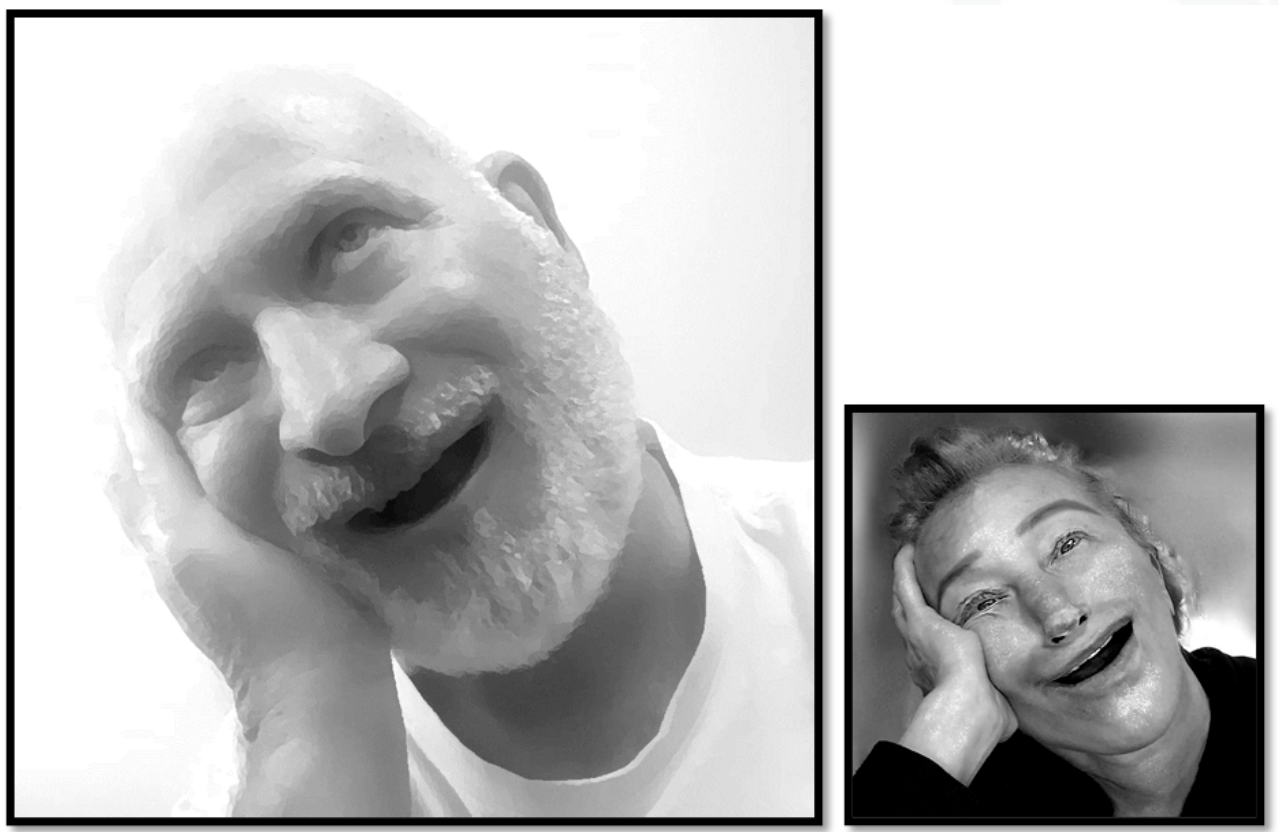

Figura 15: Cindy Sherman e Eu, imagem digital, 2020-2021. Figura 16: Autorretrato da artista, publicado em sua página do Instagram, 2021. Fonte: https://instagram.com/cindysherman?utm_medium=copy_link

Sempre ela e nunca ela! Esse parece ser o mantra visual de Cindy Sherman (1954). Sua poética é a autorreferência. A artista norte-americana se notabilizou pelas séries bem-humoradas, em que exerce o escrutínio das sociedades contemporâneas pela ótica feminina.

Aclamada pela crítica e pelo mercado, recentemente abdicou do sistema da arte para comunicar suas imagens fotográficas adulteradas por programas de tratamento de imagem nas redes sociais. Em especial, o Instagram.

Suas personagens apresentam anatomias desviadas, deformadoras. São divertidíssimas ou dramáticas e sempre inseridas em cenários surpreendentes.

Seguindo a decisão de Sherman, não por acaso as minhas Fun Selfies, de forma complementar a esta publicação, deverão ser primeiramente expostas no "insta". 


\section{Ato 9 - Mascotes! Citando I Love You.}

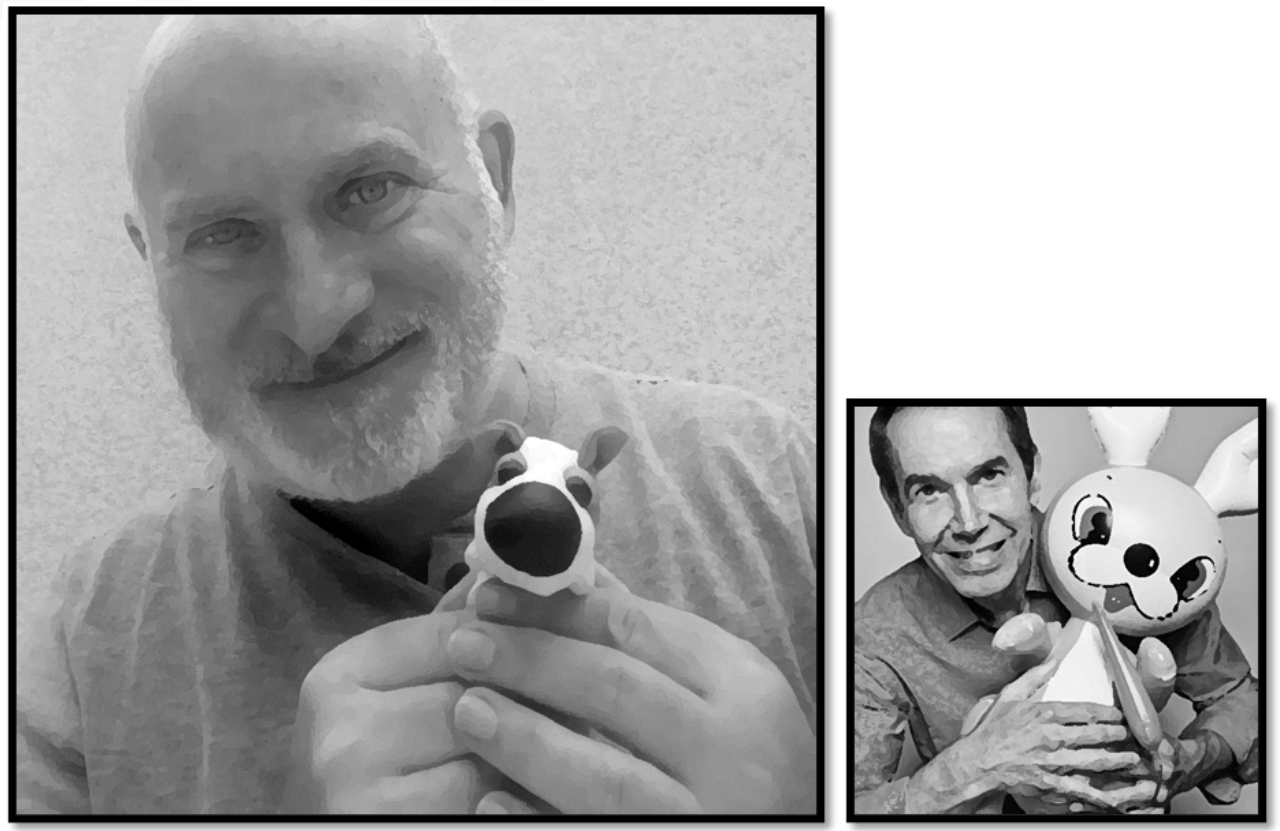

Figura 17: Jeff Koons e Eu, imagem digital, 2020-21.

Figura 18: Retrato de divulgação, na página do artista, no site da Galeria Gagosian, 2021. Fonte: https://gagosian.com/artists/jeff-koons/

O novaiorquino Jeff koons (1955) sempre adotou uma conduta multimedial. Artista líder de um ultra produtivo estúdio, apresenta um amplo portfólio de temas: as imagens clássicas, as imagens pornográficas, a indústria cultural... e os personagens infantis - exuberantemente representados por bonecos infláveis.

Seus balloon dogs, por exemplo, traçam intensa analogia com um personagem que criei logo no início de minha tardia adesão às redes sociais: o I Love You, o cachorrinho do Facebook (meu alter ego).

Descaradamente, Koons exprime seus contínuos retornos ao universo infantil, instaurando um imaginário afetivo. 


\section{DESPERSONALIZAÇÃO, O CAMINHO INVERSO.}

Olhe a mim, isto basta, eu sou arte. (VAUTIER, 1973, p. 54)

Produzida durante a pandemia de 2020-21, com o intuito de realizar uma futura exposição virtual, a ser publicada na página do instagram do Grupo de Pesquisa (CNPq) Arte e Linguagens Contemporâneas - aTempo - a série Fun Selfies deseja ser a reafirmação da figura do artista. Afinal: desde a modernidade que o artista conquista uma liberdade plena tanto no seu modus operandi como nas suas relações com o público e com a crítica. (FERRARI, 2001, p.166)

A série nasce como ato criativo contínuo à experiência de pesquisa pós-doutoral-IA, UNESP, 2012 - na qual foram estabelecidos diálogos metodológicos com alguns artistas - para definir o conceito de imagens reprográficas. O que nomeei metodologias emprestadas seria, então, a apropriação e atualização de procedimentos técnicos daqueles artistas em minha própria produção visual.

Agora, revendo, criativamente, os fios soltos da pesquisa percebi que seria também fascinante replicar suas fisionomias e posturas expressivas, adotando o não mimético $^{3}$. Então, num processo de apropriação, desconstrução e reconstrução, Rizolli toma, para ele, as almas dos artistas! Por intermédio de visualidades rebaixadas, divertidas... Parcialmente (in)fiéis. (MELLO, 2021).

E, finalizando este ensaio visual, considerando a eterna permanência das imagens da arte, pratico o sugerido por Lispector e em direção ao caminho inverso atualizo, aqui, a epígrafe de seu texto - uma frase de Bernard Berenson, lapidarmente escolhida: Uma vida plena pode ser aquela que alcance uma identificação tão completa com o não-eu que não haja mais um eu para morrer. 


\section{BIBLIOGRAFIA CITADA}

LOURENÇO, M.C.F. Excertos mínimos extraídos do texto Outro Ato. São Paulo:

Revista ARA, 2021. Disponível em

https://www.revistas.usp.br/revistaara/announcement/view/1149

DUCHAMP. M. Entrevista a W. Seitz. New York: Vogue, 1963.

FERRARI, S. Arte Contemporânea. Lisboa: Presença, 2001.

LISPECTOR, C. A paixão segundo G.H. Rio de janeiro: Nova Fronteira, 1979.

MELLO, R.L.S, Texto de apresentação da exposição virtual FUN SELFIES. Instagram: @arte.linguagens.contemporaneas, 2021.

VAUTIER, B. Arte = Ben. Entrevista a E. Lebeer. Paris: L'Art Vivant, 1973.

VAN GOGH, V. Carta ao irmão Theo, Fac-símile. Amsterdam: van Gogh Museum, 1882.

VENTURI, L. Histoire de la critique d'art. Paris: Flammarion, 1969. 